\title{
ARTIGOS| Epigrafe
}

\section{AS PRÁticAs dE CONTROLE E PUNIÇÃO NA SOCIEDADE ESCRAVISTA CAFEICULTORA DO BRASIL OITOCENTISTA: UMA ANÁLISE À LUZ DO PENSAMENTO DE MICHEL FOUCAULT}

\section{Marcelo Ferraro*}

Resumo: O presente artigo se propõe a analisar as práticas de controle e punição na sociedade escravista à luz dos estudos e categorias de Michel Foucault, comparando três contextos: a Casa de Correção da Corte no Rio de Janeiro, as grandes plantations escravistas do Vale do Paraíba, e as casas de câmara e cadeia dos núcleos urbanos dessa mesma região. O artigo se desenvolve em três partes, cada qual correspondente a um dos três contextos e espaços. A primeira estabelece um diálogo com Andrei Koerner e seus estudos sobre as práticas punitivas e os saberes jurídicos na sociedade escravista brasileira. A segunda remete aos estudos de Rafael de Bivar Marquese sobre as plantations escravistas da cafeicultura do Vale do Paraíba, e sobre as teorias agronômicas e de administração do trabalho escravo do século XIX . Por sua vez, a terceira parte apresenta uma interpretação da permanência das casas de câmara e cadeia nos núcleos urbanos do interior do território no século XIX. A comparação entre os diferentes estudos a partir das contribuições teóricas de Michel Foucault oferece novas possibilidades interpretativas sobre a sociedade escravista do Império do Brasil.

Palavras-chave: Escravidão; Foucault; Punição; Século XIX; Brasil Império.

Ao tratar das características e origens das práticas disciplinares de poder em seu artigo "O Nascimento do Hospital”, Michel Foucault reafirma que não seriam técnicas inventadas no século XVIII, mas surgidas anteriormente de forma difusa, em algumas práticas e instituições específicas, sendo apenas reelaboradas nesse século e tornadas posteriormente hegemônicas. Entre as instituições onde teria se originado difusamente práticas de poder disciplinares, como os espaços destinados

\footnotetext{
* Graduação em História pela Universidade de São Paulo - USP.
} 


\section{ARTIGOS| Epígrafe \\ MARCELO FERRARO}

aos loucos e organizações militares, o autor se refere às "grandes empresas escravistas nas colônias"(FOUCAULT, 1979, p.105).

Dessa afirmação surgiu o interesse na apropriação do instrumental teóricoconceitual de Foucault para analisar as práticas punitivas na sociedade escravista brasileira. Evidentemente, não se trata de uma proposta inédita, eis que outros estudos já se engajaram nessa tentativa, entre os quais se destacam os de Andrei Koerner, ao qual retornaremos mais adiante. Todavia, esses estudos se detiveram, predominantemente, nas práticas punitivas oficiais na Corte do século XIX. Por sua vez, esse estudo pretende abordar as práticas punitivas no coração da escravidão oitocentista, focando os espaços urbanos e rurais do Vale do Paraíba, centro da cafeicultura.

Embora Foucault se refira a práticas disciplinares no período colonial, nos parece mais profícuo o recorte temporal do século XIX, eis que se trata do período de ascensão e consolidação da hegemonia do poder disciplinar na França. O objetivo é realizar uma análise que permita comparar tais práticas nessas diferentes sociedades do universo oitocentista, extraindo hipóteses e interpretações a partir das semelhanças e divergências.

\section{I) SOBERANIA E DISCIPLINA NA PASSAGEM DO SÉCULO XVIII PARA O SÉCULO XIX}

Em “Vigiar e Punir", Foucault apresenta uma transformação nas práticas punitivas na passagem do Antigo Regime para a Sociedade Burguesa, em um processo complexo, não linear nem evolutivo.

Até o século XVIII predominaria uma forma de organização social e de expressão do poder pautadas pela ostentação. Vigeria uma economia política das práticas punitivas expressivas da figura do poder soberano/real. Era adotada a tecnologia punitiva do suplício, que embora esporádico, era ostensivo. Não se trata um ato cruel e irracional, mas de uma lógica específica, que faz dele ao mesmo tempo

um procedimento técnico e um ritual. Como procedimento técnico, o suplício pretende produzir uma quantidade de sofrimento que possa ser 


\title{
ARTIGOS| Epígrafe \\ AS PRÁTICAS DE CONTROLE E PUNIÇÃO NA SOCIEDADE ESCRAVISTA CAFEICULTORA DO BRASIL OITOCENTISTA: UMA ANÁLISE À LUZ DO PENSAMENTO DE MICHEL FOUCAULT
}

\begin{abstract}
apreciada, comparada, hierarquizada, modulada de acordo com o ato cometido. (...) Como ritual, visa marcar o corpo da vítima, tornar infame o criminoso, ao mesmo tempo que a violência que marca é ostensiva, caracteriza-se pela demonstração excessiva do poder daquele que pune(SALLA;GAUTO; ALVAREZ, 2006, p.337).
\end{abstract}

Já no século XIX tornou-se hegemônica uma nova forma de organização social e de expressão do poder e das práticas punitivas, pautadas pelo adestramento dos indivíduos, pela docilidade e produtividade dos corpos e mentes, a partir da vigilância constante e da introjeção das normas pelos indivíduos. Essa forma de expressão do poder implica uma organização e um controle meticulosos do espaço, do tempo e das atividades.

Fundamentalmente, nessa obra Foucault procura compreender a progressiva (mas não linear) substituição do espetáculo do suplício - expressão do poder soberano - por essa nova modalidade de punição, voltada para o controle constante a para a construção de mentes e corpos dóceis (FOUCAULT, 2004).A própria organização do livro orienta a leitura a enxergar nessa mudança uma relação de oposição entre poder soberano e poder disciplinar, como se Soberania e Disciplina fossem categorias excludentes. Todavia, em textos posteriores, como "Soberania e Disciplina" (FOUCAULT, 1979), tal relação não seria necessariamente antagônica, de forma que ambas as categorias chegaram a coexistir e inclusive a se articular. $^{1}$

Nesse trabalho, ambas as categorias serão utilizadas como tipos ideias (no sentido weberiano) de economia política das práticas punitivas e de tecnologias do poder: o poder soberano, esporádico e ostentatório, e o poder disciplinar, pautado pela vigilância constante, pelo fomento ao autocontrole, à docilidade de mentes e à produtividade de corpos. Nesse sentido, cabe questionar a validade dessas categorias para a análise das práticas punitivas e de controle social na sociedade brasileira oitocentista, o que nos leva a um diálogo direto com Andrei Koerner.

\footnotetext{
${ }^{1}$ Segundo Sérgio Adorno (2006), as leituras das categorias como contrapostas decorreria da própria formacomo Foucault redigiu sua obra 'Vigiar e Punir', mas que tratar-se-ia de uma escolha de ordem metodológica, e não da construção de conceitos excludentes.
} 


\title{
II)ANDREI KOERNER - AS PRÁTICAS PUNITIVAS (UMA TECNOLOGIA POLÍTICA DO CORPO) E OS SABERES JURÍDICO-PENAIS NA SOCIEDADE ESCRAVISTA BRASILEIRA DO SÉCULO XIX
}

Em dois artigos, Koerner (2001; 2006) se propõe a uma

\begin{abstract}
análise das práticas punitivas na sociedade escravista brasileira do século XIX, com o objetivo de esboçar a tecnologia política do corpo daquela sociedade e suas consequências para o pensamento jurídico penal. (...) A análise concentra-se nas relações entre as práticas punitivas estatais e as estratégias de produção de submissão produtiva dos indivíduos naquela sociedade. (KORNER, 2006, p. 205).
\end{abstract}

O autor busca compreender as especificidades das relações de poder e as formas de saber (pensamento jurídico penal) em uma sociedade escravista e organizada como uma monarquia constitucional.

Ao analisar a validade das categorias foucaultianas para a sociedade escravista, Koerner ressalta suas peculiaridades. Primeiramente, trata-se de uma sociedade na qual não se configura plenamente o monopólio da violência legítima, eis que autoridades públicas e particulares (senhores) compartilham essa prerrogativa. O Império brasileiro conteria uma espécie de soberania compartilhada entre o Estado e os senhores (de terras e escravos), sendo que esses detinham prerrogativas bastante amplas ante seus subordinados (esposas, filhos e escravos). Ademais, esses mesmos senhores tenderam a ocupar os cargos públicos do Estado em formação, de forma que exerciam ao mesmo tempo prerrogativas da soberania estatal e de sua soberania particular, em suas terras e sobre seus subordinados.

Partindo dessas premissas, Koerner parte para uma análise da arquitetura da Casa de Correção da Corte do Rio de Janeiro (CCC-RJ). Embora teoricamente tivesse seguido o modelo arquitetônico do panóptico de Benthan, a CCC-RJ não se constituiu plenamente segundo seu projeto. Todavia, os desvios não dever-se-iam a uma cópia mal feita ou a equívocos formais, mas decorreram da forma peculiar como as práticas punitivas estatais se relacionavam com a sociedade escravista. Ou seja, a análise dos desvios seria precisamente o que explicaria as particularidades da 


\section{ARTIGOS| Epigrafe \\ AS PRÁTICAS DE CONTROLE E PUNIÇÃO NA SOCIEDADE ESCRAVISTA CAFEICULTORA DO BRASIL OITOCENTISTA: UMA ANÁLISE À LUZ DO PENSAMENTO DE MICHEL FOUCAULT}

relação da sociedade brasileira no tocante às práticas punitivas e tecnologias de controle e poder (KOERNER, 2006, pp. 217).

O panóptico de Benthan implicaria uma plena visibilidade de todos os presos e, concomitantemente, a invisibilidade do vigia (ser visto sem ver seu vigia), fomentando um maior autocontrole e um exercício impessoal do poder, nos termos da categoria do poder disciplinar. Já os desvios da CCC-RJ implicavam na ocorrência de espaços de invisibilidade. Para além de meros equívocos na construção, esses desvios implicariam um regime de visibilidade que demandaria a manutenção de um vigilante presente. Ou seja, a vigilância seria apenas parcialmente impessoal, sendo mantida a figura do vigilante e de seu arsenal punitivo à mostra. Eram mantidos elementos centrais da dominação pessoal, vitais na sociedade escravista, paternalista e clientelista. À distância na hierarquia social corresponderia uma proximidade física como elemento vital à manutenção dessa forma de dominação (KOERNER, 2006, pp. 219-220).

Koerner estende sua tese para além dos espaços da Casa de Correção, concluindo que tais técnicas de controle e de punição estariam presentes nos espaços públicos urbanos. Essa colocação nos será útil mais adiante, quando serão comparados o Vale do Paraíba e a Corte, e em seguida espaços urbanos (vilas e cidades) e rurais (plantations) do próprio Vale.

A partir dos pressupostos e hipóteses interpretativas apresentadas, Koerner conclui pela impossibilidade do "Panóptico Tropical Escravista":

(...) Seria possível um hipotético 'panóptico tropical-escravista'? O panóptico poderia constituir um modelo das relações de poder de uma sociedade fundada no latifúndio escravista?

O panóptico somente seria um modelo das relações sociais na medida em que se negasse enquanto panóptico - uma torre de onde tudo se vê, a disciplina agindo nos corpos e a norma social inscrita na consciência dos indivíduos como padrão de comportamento de um indivíduo médio abstrato. Na sociedade escravista, não só a generalidade da lei do soberano não atingia a totalidade dos indivíduos no território, como também o indivíduo abstrato não existe, pois esse tipo de sociedade implica a diferenciação dos indivíduos segundo sua condução. A condição social dos indivíduos significava a sua classificação segundo critérios como estatuto jurídico, riqueza e prestígio social, este considerado sob o aspecto da sua inserção nas redes de troca de favor. Os indivíduos são 


\section{ARTIGOS| Epigrafe \\ MARCELO FERRARO}

classificados em categorias sociais hierarquizadas em distinções que assumem uma dimensão quase ontológica (KOERNER, 2001, pp. 215-216).

Portanto, no 'panóptico tropical escravista' não se completa a diluição do vigilante em um olhar invisível e impessoal. A partir da análise da CCC-RJ, Koerner propõe uma hipótese referente à sociedade escravista brasileira, na qual vigeria um outro regime de saber-poder. Não se trata de um modelo punitivo similar ao suplício, eis que não afirma apenas o poder real/soberano, e tampouco um modelo disciplinar, no qual se reafirma a impessoalidade da norma. Tratar-se-ia de um modelo específico, no qual as tecnologias de controle e punição obedecem a critérios de classificação social dados a priori, de forma que sua aplicação reafirma a hierarquia social vigente, bem como a dominação pessoal dos senhores sobre seus subordinados e agregados.

No que se refere especificamente aos escravos, ser-Ihe-iam aplicadas técnicas disciplinares específicas, que combinariam elementos do suplício. Ou seja, na sociedade escravista brasileira, a produtividade dos escravos não é obtida pela introjeção da norma pelo indivíduo, mas por meio da intimidação próxima, contínua e regular. Assim, não se trata do modelo punitivo do suplício - esporádico ostentatório - e tampouco da disciplina - constante e utilitário (justa medida para o objetivo da docilidade e produtividade) -, mas de uma modalidade específica, que combina violência física ou ameaça de violência constante, relações de afeição e/ou favor, e vigilância pessoal, proximidade física (dominação pessoal) (KOERNER, 2006, pp. 229-230).

A tais tecnologias de poder correspondeu a construção de um saber, um discurso político-jurídico que mesclaria elementos do liberalismo nascente e da tradição católica, patriarcal e paternalista, de origem ibérica e presente desde o período colonial. Um discurso jurídico e moral da família, marcado pela regra do paternalismo. Em vez da impessoalidade da Lei, o paternalismo se pauta pela lógica ultra personalista do Favor (FRANCO, 1997).elemento central nas relações entre senhores e escravo, e entre senhores e homens livres e pobres - em especial os libertos e agregados (KOERNER, 2006, p. 230). 
Assim, o discurso paternalista predominaria como norte das relações de poder e das práticas punitivas na sociedade escravista, marcando inclusive $\mathrm{o}$ sistema normativo em construção (KOERNER, 2006, p. 230). De forma concomitante e articulada constituíram-se técnicas de controle e punição e saberes jurídicos que não se opuseram, mas se articularam, ao discurso paternalista. Formava-se uma monarquia constitucional cuja soberania era compartilhada entre Estado e senhores (assim como o direito ao exercício da violência legítima), um ordenamento jurídico pautado por hierarquias sociais positivadas ou tácitas, e práticas de controle e punição marcados por um tipo híbrido de poder, que continha características do poder soberano e do poder disciplinar, bem como traços próprios.

A sociedade brasileira, monarquista-constitucional e escravista, formava suas próprias tecnologias de poder e seus correlatos saberes jurídicos, em uma articulação sui generis, mas que permitiu a esse regime político e a essa estrutura social sobreviverem até quase a última década do século XIX, em um dos períodos de maior estabilidade social e institucional da história do país.

\section{III) O RURAL E O URBANO NA SOCIEDADE ESCRAVISTA BRASILEIRA DO SÉCULO}

\section{XIX: AS PLANTATIONS ESCRAVISTAS E AS CASAS DE CÂMARA E CADEIA}

Segundo a tese de Andrei Koerner, a sociedade escravista brasileira do século XIX teria dado origem a uma tecnologia específica do poder, que mesclaria elementos do poder soberano e do poder disciplinar, além de apresentar características próprias. Nos termos apresentados pelo autor dessa tese, essa forma de expressão do poder seria característica de toda a sociedade brasileira do século $\mathrm{XIX}$, permeando os espaços prisionais, as ruas e espaços urbanos, e também as plantations.

Todavia, embora bastante profícua e fundamentada a interpretação de Koerner, a presente pesquisa busca questionar a existência de uma única tecnologia de controle e punição predominante nesses diferentes espaços. São espaços 


\section{ARTIGOS| Epírafe \\ MARCELO FERRARO}

dotados de funções sociais diversas e permeados por agentes sociais (e posições sociais) específicos.

A hipótese a ser levantada remete à existência de espaços nos quais as tecnologias de poder aproximar-se-iam do modelo disciplinar, e outros nas quais aproximar-se-iam do poder soberano. Cabe-nos demonstrar as especificidades desses espaços, analisar as eventuais diferenças nas tecnologias de controle e punição, bem como interpretá-las.

\section{A) AS PLANTATIONS ESCRAVISTAS OITOCENTISTAS: UM DIÁLOGO COM RAFAEL MARQUESE}

No que se refere aos espaços rurais, essa pesquisa se pauta pelos estudos de Rafael Marquese, referentes àpaisagem e à arquitetura da escravidão nas grandes plantations oitocentistas do Vale do Paraíba, assim como sua tese sobre as teorias agronômicas e de gestão do trabalho escravo.

No primeiro estudo, Marquese investigou a disposição espacial e a relação entre casas de vivenda senhoriais, as moradias escravas e os processos produtivos, buscando compreender o peso que função e representação social cumpriam na ordenação da paisagem e dos ambientes construídos. Entre suas conclusões, o autor sugere que a plantation escravista brasileira sofre amplas transformações na passagem do período colonial para o Império, sendo que sua disposição arquitetônica segue progressivamente uma lógica de produtividade, em consonância com a revolução industrial. A cafeicultura brasileira somente teve condições de se atrelar ao mercado mundial pós-revolução industrial por ter adotado um modelo produtivo altamente desenvolvido e articulado aos ditames da economia-mundo do século XIX. Trata-se de uma plantation moderna, com progressivo desenvolvimento tecnológico e organizada segundo uma lógica semiindustrial, ainda que pautada no trabalho escravo (MARQUESE, 2006). 


\section{ARTIGOS| Eppigrafe \\ AS PRÁTICAS DE CONTROLE E PUNIÇÃO NA SOCIEDADE ESCRAVISTA CAFEICULTORA DO BRASIL OITOCENTISTA: UMA ANÁLISE À LUZ DO PENSAMENTO DE MICHEL FOUCAULT}

E ao se referir à escravidão do Brasil oitocentista, Marquese adota o conceito de Segunda Escravidão ${ }^{2}$ cunhado pelo historiador Dale Tomich, segundo o qual não tratar-se-ia de uma simples manutenção da escravidão colonial, mas de uma reinvenção da escravidão no contexto de Estados Nacionais constituídos (Brasil e Estados Unidos) e engajada num sistema produtivo articulado à economia-mundo pós revolução industrial. ${ }^{3} \mathrm{Na}$ passagem do século XVIII para o XIX, diferentes oportunidades se apresentaram na economia mundial para a produção de artigos como o açúcar, o café e o algodão. Diferentes regiões competiram arduamente até consolidarem fatias de mercado (e até monopólios virtuais) de tais produtos. Nesse processo, venceram aquelas que desenvolveram as melhores condições e técnicas para a produção - de forma simplificada, o Sul dos Estados Unidos com o algodão, Cuba com o açúcar, e o Brasil com o café (essencialmente no Vale do Paraíba). Ao mesmo tempo, as demandas de uma economia mundial pautada pela revolução

\footnotetext{
2“Em um ensaio pioneiro publicado originalmente há vinte anos, Dale Tomich propôs a categoria 'segunda escravidão', para apreender em um quadro conjunto a novidade da escravidão atlântica oitocentista. De acordo com seu argumento, as modificações ocorridas com o advento da economiamundo industrial do século XIX impuseram aos senhores de escravos americanos a necessidade do aumento constante da produtividade de seus cativos, sob o risco de se verem excluídos do mercado mundial. (...) Nesse movimento, os destinos do Sul dos Estados Unidos, de Cuba e do Brasil - cada qual se especializando na produção escravista, em larga escala, de algodão, açúcar e café entrelaçaram-se de modo estreito. Em cada uma dessas novas fronteiras da mercadoria surgiram unidades produtivas escravistas com plantas inéditas, cujas combinações de terra, trabalho e capital romperam com os padrões anteriormente vigentes no mundo atlântico" (MARQUESE, 2010, pp. 8384)

"A segunda escravidão consolidou uma nova divisão do trabalho e forneceu um volume considerável de matérias-primas e gêneros alimentícios aos poderes industriais centrais. Longe de ser uma instituição moribunda durante o século XIX, a escravidão demonstrou toda a sua adaptabilidade e vitalidade.

(...) A competição dos preços num mercado em expansão e o crescimento do trabalho assalariado tornaram mais importante a produtividade do trabalho. (...) Os produtores escravistas tinham de competir entre si e com outros produtores periféricos, e sua posição nas relações de produção internacionais foram determinadas pelo preço das matérias-primas. Ao mesmo tempo, os diferenciais de preço foram nivelados pela produção industrial e pelo mercado mundial integrado, com o estabelecimento de preços mundiais. (...).

Ao mesmo tempo que a hegemonia britânica criava um mercado mundial integrado, as condições para a produção e a reprodução das relações sociais de capital foram-se tornando "nacionais": as condições impostas pela divisão internacional do trabalho ocasionaram uma variedade de respostas políticas por parte das classes senhoriais de Cuba, da América do Sul e do Brasil. Ao contrário de seus predecessores coloniais, elas desenvolveram variados graus e modos de autoconsciência nacional por intermédio dos quais tentaram consolidar sua posição na economia mundial. (...) Ademais, os proprietários de escravos tinham de ser empresários preocupados com a produtividade do trabalho (...)" (TOMICH, 2011, pp. 96-97).
} 


\section{ARTIGOS| Epigrafe}

MARCELO FERRARO

industrial e pela construção de um mercado de consumo de massa demandavam produtos cada vez mais baratos, o que forçava os produtores a refinarem suas técnicas e extraírem o máximo de produtividade dos trabalhadores escravos e das terras cultivadas. Esse processo levou a uma alteração profunda nas relações de trabalho nas plantations escravistas. Aquelas que conseguiam atender às demandas do mercado mundial passaram a organizar a produção de forma minuciosamente organizada segundo os ditames da máxima produtividade. No tocante à mão-deobra, os escravos tornaram-se nesse período exponencialmente mais produtivos, multiplicando progressivamente seus resultados, de forma que essa forma de escravidão não mais podia ser compreendida como uma continuação da escravidão colonial. Tratava-se de uma nova forma de escravidão, uma Segunda Escravidão.

Esse regime produtivo dizia respeito principalmente às grandes plantations escravistas, diretamente articuladas ao mercado mundial. Assim, ao nos referirmos aos espaços rurais do Vale do Paraíba, focamos especialmente essas grandes unidades produtivas, deixando de lado o papel significativo - porém percentualmente reduzido nas exportações brasileiras - dos pequenos proprietários de terras e escravos.

As grandes plantations que se melhor se adaptaram às demandas da economia mundial fomentaram o desenvolvimento de técnicas produtivas mais eficientes As novas teorias e técnicas da produção exigiram uma reconfiguração das estratégias no trato com os trabalhadores escravos. É nesse sentido que apontam os estudos de Marquese em sua tese de doutorado "Feitores do Corpo, Missionários da Mente". Segundo essa pesquisa, ter-se-ia constituído um campo de saberes agronômicos compartilhado, contendo uma nova teoria da gestão escravista no século XIX (uma relação saber-poder) (MARQUESE, 2004, pp. 267-268).

Analisando algumas dessas obras de teoria agronômica e de gestão do trabalho escravo, Marquese conclui que inaugurou-se no século XIX

uma forma inédita de encarar a administração do trabalho escravo nas propriedades rurais brasileiras, (...)a administração dos escravos tornavase objeto de uma reflexão minuciosa, que dava conta de vários aspectos da vida da escravaria sob o comando de um único senhor (...). O cerne 


\title{
ARTIGOS| Epigrafe \\ AS PRÁTICAS DE CONTROLE E PUNIÇÃO NA SOCIEDADE ESCRAVISTA CAFEICULTORA DO BRASIL OITOCENTISTA: UMA ANÁLISE À LUZ DO PENSAMENTO DE MICHEL FOUCAULT
}

\begin{abstract}
desse modelo deitava raízes em dois aspectos interligados: por um lado, recorrendo à imagem do acampamento militar para caracterizar a gerência escravista, a defesa do primado da disciplina como essencial à condução dos escravos; por outro lado, a concepção da religião como freio e o estímulo à formação de casais como passos necessários para a constituição de uma comunidade escrava na propriedade rural. Disciplina severa e paternalismo, portanto, conjugavam-se como os dois mecanismos basilares da administração dos escravos e, consequentemente, do sucesso econômico do proprietário rural (MARQUESE, 2004, pp. 279-280).
\end{abstract}

Os manuais agronômicos analisados por Marquese remetiam diretamente ao controle e gestão da mão-de-obra escrava. Nesse sentido, são precisamente saberes constituídos a partir das práticas de poder exercidas por esses senhores. Toda uma experiência de poder conferindo-lhes saberes capazes de fomentar uma gestão mais produtiva do trabalho escravos. Entre as obras analisadas por Marquese, estão o "Manual do Agricultor Brasileiro", de Carlos Augusto Taunay, e a "Memória sobre a Fundação de uma Fazenda na Província do Rio de Janeiro", de Francisco Peixoto de Lacerda Werneck. Entre os excertos apresentados por Marquese, nos quais esses e outros autores se referem à gestão da escravaria, estão os seguintes.

Nos termos de Calor Augusto Taunay:

Ei-nos pois obrigatoriamente com uma rigorosa disciplina nos campos? $\mathrm{E}$ mormente nas grandes fábricas, onde uma perpétua vigilância e regra intransgressível devem presidir aos trabalhos, ao descanso, às comidas, e a qualquer movimento dos escravos, com o castigo sempre à vista. $\mathrm{A}$ maior ou menor perfeição nessa disciplina determina o maior ou menor grau de prosperidade dos estabelecimentos (TAYNAY, 2001, p. 55).

quem observar estas máximas, conhecerá que não é difícil conservar a disciplina mais rigorosa, com bem poucas correções, pois que o excesso de castigo e repetição contínua, longe de corrigirem, embrutecem, não devendo ser permitido aos feitores o castigarem imediatamente, senão na ocasião da desobediência com revolta, que é o maior dos crimes domésticos, e ao qual deve aplicar-se depois o máximo do castigo, seja qual for a dose instantânea que o réu tiver levado (TAYNAY, 2001, pp. 67$68)$.

onde a sombra da disciplina que tinham organizado ainda se conserva a descendência dos seus escravos. Portanto, o senhor humano que tiver estabelecido uma disciplina razoável e regularmente observada em sua fazenda, e equiparado pouco mais ou menos o número dos machos e das fêmeas, pode contar que com bem poucas compras conservará a sua escravatura completa e a transmitirá aos filhos melhor, mais dócil e mais 


\title{
ARTIGOS| Epigrafe \\ MARCELO FERRARO
}

adestrada, se souber convenientemente educar e tratar os crioulos (TAUNAY, 2001, pp. 76-78).

Como se observa, trata-se precisamente de uma economia política de produtividade dos corpos dos escravos, e de fomentação de uma docilidade de suas mentes. É interessante observar que, embora não se rompa com a pessoalidade nas relações de poder, essa forma de administração e controle dos escravos se aproxima dos termos do poder disciplinar descrito por Foucault.

Por sua vez, para Francisco Peixoto de Lacerda Werneck, nas palavras de Marquese:

\begin{abstract}
Já na abertura do trabalho Werneck recomendou cuidado com a saúde dos escravos e vigilância estrita sobre os mesmos, ao traçar as instruções para a construção da senzala. Esta deveria ser erguida em uma só linha, (...); cada cubículo deveria acomodar quatro escravos solteiros e, no caso dos casais, marido e mulher com os filhos. As portas dos cubículos estariam voltadas ao quadro da fazenda, que confirmava uma espécie de pátio em torno do terreiro, sendo cada face ocupada respectivamente pela casa do senhor, pelos paióis, armazéns, e cavaliças, pelos engenhos de pilóes e de mandioca, e pela senzala: assim a moradia escrava permaneceria sempre sob a vista e o controle do senhor (MARQUESE, 2004, pp. 281-282).
\end{abstract}

Trata-se do padrão arquitetônico dos barracões cubanos:

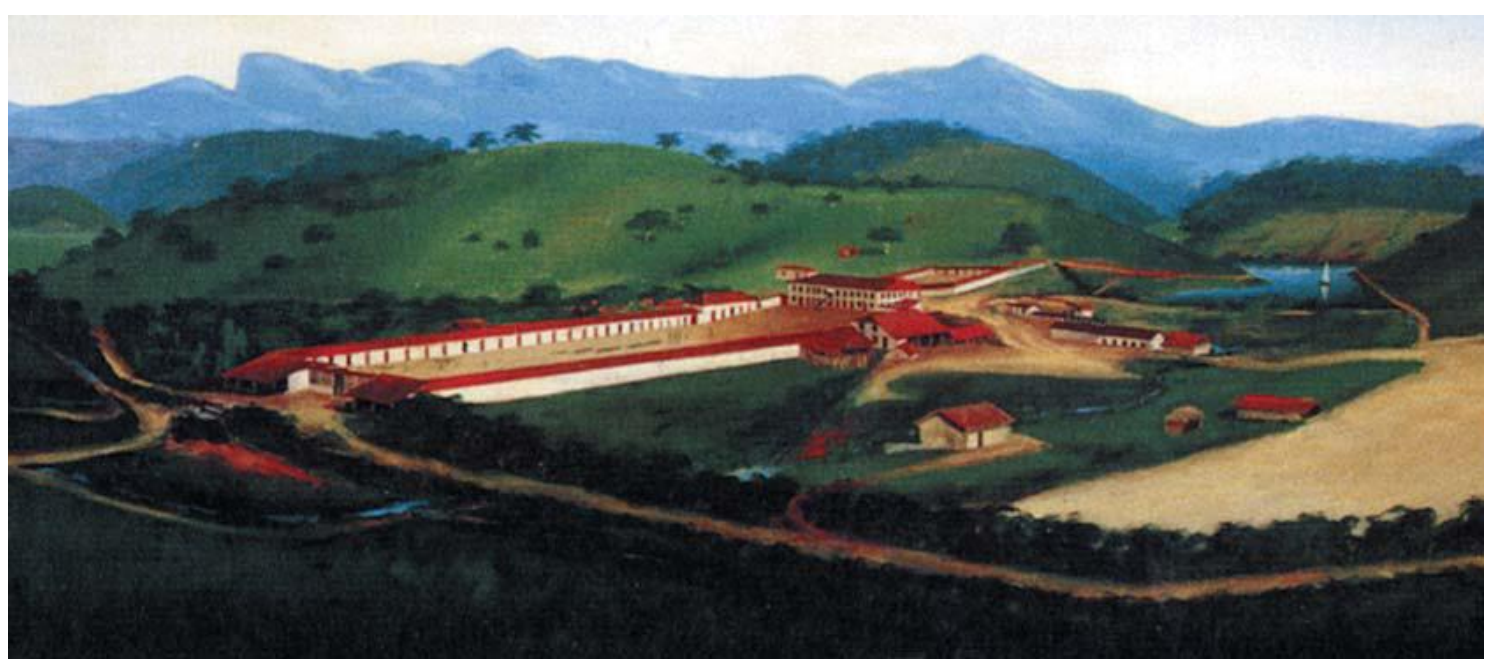




\section{ARTIGOS| Epírafe \\ AS PRÁTICAS DE CONTROLE E PUNIÇÃO NA SOCIEDADE ESCRAVISTA CAFEICULTORA DO BRASIL OITOCENTISTA: UMA ANÁLISE À LUZ DO PENSAMENTO DE MICHEL FOUCAULT}

FIGURA $1^{4}$
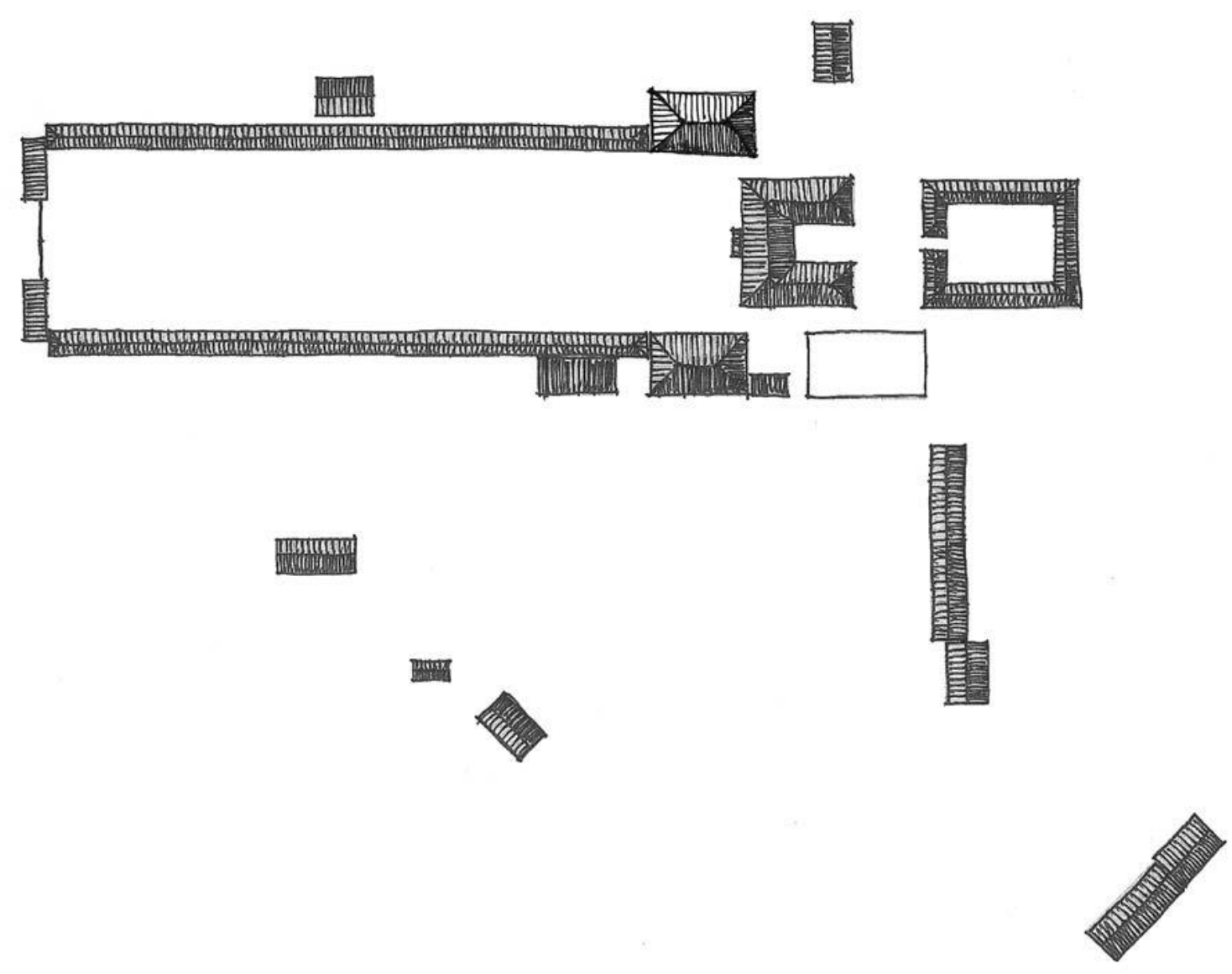

FIGURA 2.5

Ainda segundo Werneck:

O administrador, meia hora antes de romper o dia, deve mandar tocar a chamada, à qual acodem de pronto, e a um ponto já designado toda a escravatura dos diversos trabalhos; formam-se com a separação dos dois sexos, e por altura, ficando os mais altos à direita, e as mulheres defronte os homens. Os feitores tomam o centro; passa-lhe uma revista para ver os que faltam, tomando nota se por doentes, se por omissão ou por fuga; dá alta aos restabelecidos do hospital, e recolhe a ele todos os que se acham enfermos; observa se eles têm a ferramenta próprio do trabalho do dia, cuja ordem deve ser dada de véspera. Imediatamente os mandará persignar-se e rezar duas ou três orações, seguindo logo ao seu destino com o feitor na retaguarda (WERNECK, 1985, p. 61).

\footnotetext{
${ }^{4}$ Georg Grimm [atribuição], Fazenda Boa Vista (detalhe), Bananal, SP, óleo sobre tela, ca. $1880,74 \mathrm{~cm}$ X 144cm (SETUBAL, 2004, p.160; MARQUESE, 2006, p. 26).

${ }^{5}$ Osmar Cassiano Gomes Jr., Fazenda Boa Vista, 2005, planta baixa (MARQUESE, 2006, p.26).
} 


\section{ARTIGOS| Epigrafe \\ MARCELO FERRARO}

Nos termos de Marquese:

Toque de chamada, classificação dos escravos em filas conforme sexo e altura, revista pelos feitores, distribuição das ferramentas, partida para o campo com o feitor na retaguarda: a despeito de Werneck não empregar explicitamente a imagem do exército para caracterizar essas atividades, não há como negar que o padrão disciplinar recomendado aproximava-se muito da prática militar (MARQUESE, 2004, p. 282).

Outro manual citado por Marquese é o do Padre Antonio Caetano da Fonseca, que contém afirmações como:

Quando os meninos passarem de cinco anos devem ir aprendendo alguma doutrina cristã, e principiar a trabalhar em serviços que forem compatíveis com as suas forças, porém por pouco tempo; pois é isso tão somente para moralizá-los e para desenvolver e fortificar seus músculos, e não para tirar fruto do seu trabalho; pois só de dez anos por diante podem dar algum serviço a seus senhores (FONSECA, 1864, p. 101).

A partir das fontes documentais analisadas, Marquese conclui que a teoria oitocentista brasileira sobre a administração dos escravos se pautou por uma conjugação estreita entre disciplina e paternalismo (MARQUESE, 2004, p. 292).

Em outro artigo, Marquese remete ao que denomina de Regime Visual da Segunda Escravidão. Analisando as práticas de controle dos escravos nas plantations do século XIX, o autor apresenta a dimensão visual do poder, em reflexões que permitem um interessante diálogo com as ideias de vigilância no poder disciplinar de Foucault. Segundo Marquese, a organização arquitetônica da plantation obedecia tanto a critérios de produtividade como de controle da escravaria. Esse controle dar-se-ia tanto pela composição quase militar da plantation, como pela organização dos campos visuais por meio dos quais os escravos eram observados em suas atividades (MARQUESE, 2010).

Após visitar fazendas da região entre 1883 e 1884, o agrônomo holandês C. F. van Delden assim a elas se referiu:

A aparência de uma fazenda-fábrica brasileira é raramente alegre. Grandes edifícios com dois pavimentos, ladeados por linhas de edifícios menores dispostos em um quadrilátero que constituem as habitações dos escravos e dos trabalhadores livres, a casa do médico, enfermarias e armazéns, afora os extensos terreiros para a secagem [...] tudo isso dá ao estabelecimento a aparência de uma fortaleza, não de um centro agrícola, 


\title{
ARTIGOS| Epigrafe \\ AS PRÁTICAS DE CONTROLE E PUNIÇÃO NA SOCIEDADE ESCRAVISTA CAFEICULTORA DO BRASIL OITOCENTISTA: UMA ANÁLISE À LUZ DO PENSAMENTO DE MICHEL FOUCAULT
}

ainda mais porque tudo está cercado por muros e paliçados de forma que o lugar pode ser trancado à noite (DELDEN LAERNE apud MARQUESE, 2010, p. 97).

É nesse sentido que Marquese se refere a essas plantations como organizações espaciais fortemente disciplinares. Cita ainda a percepção de outro viajante, Augusto Emílio Zaluar, a respeito de outra fazenda do Vale em 1859:"Esta imensa praça é fechada em torno pelas senzalas, engenho e mais oficinas, de modo que forma uma larga cidadela para onde se entra por dois grandes portões laterais" (ZALUAR apud MARQUESE, 2010, p. 97).

Os escravos alocados nas grandes plantations obedeciam a uma rotina rigorosamente planejada e imposta:

\begin{abstract}
(...) a senzala em quadra das grandes fazendas atendia tanto ao objetivo de controlar a mobilidade noturna dos cativos quanto ao de comandar, de forma estrita, o trabalho coletivo. Os registros do século XIX documentam amplamente como o agenciamento em quadra facilitava a coordenação de grupos numerosos de trabalhadores escravos por meio de procedimentos cotidianamente reiterados: o sino tocado pelo administrador/feitor antes do nascer do sol, a formação dos escravos no terreiro para a inspeção e distribuição das fainas do dia, a reza coletiva, a partida dos vários ternos (gangs) para o campo, cada qual com seus respectivos feitores de roça ou capatazes, o trabalho de secagem dos grãos no quadro sob o comando do feitor de terreiro, a reunião de toda a escravaria no quadro após o por do sol (ao que, muitas vezes, seguia o serão noturno) o toque de recolher às 20 hoo ou 21hoo, a nova contagem, a tranca dos cubículos das senzalas e do portão do quadrado (MARQUESE, 2010, p. 97).
\end{abstract}

Como se observa, trata-se de um modelo arquitetônico voltado à melhor administração dos corpos com vista à sua produtividade, com uma rígida organização dos espaços e do tempo. Marquese fala, ainda, em uma organização de espaços disciplinares dotados de rígidos protocolos de conduta. A aproximação com as instituições analisadas por Foucault nas quais predominaria o poder disciplinar é evidente.

No tocante à dimensão do Olho do Poder, da vigilância como elemento central do poder disciplinar, uma outra aproximação pode ser feita. Marquese fala 


\title{
ARTIGOS| Epigrafe \\ MARCELO FERRARO
}

em uma administração visual do trabalho escravo, por meio de novas técnicas espaciais na plantação dos pés de café:

\begin{abstract}
A cafeicultura do Vale do Paraíba apresentou algumas modificações em relação aos padrões caribenhos. Ainda que seguissem o princípio do alinhamento vertical dos pés de café, da base ao topo dos morros, os senhores de escravos do Vale adotaram um espaçamento bem maior entre os arbustos e as linhas dos cafeeiros. (...)

(...) quero ressaltar como a conjugação entre o afastamento dos pés e a produtividade das plantas possibilitou o aumento da exploração dos escravos. A chave para tanto residiu no incremento da supervisão direta sobre o processo de trabalho. Por meio do primado da visualização como meio de controle dos trabalhadores, ou seja, de uma nova forma de funcionamento do olho senhorial-escravista, os fazendeiros do Vale do Paraíba impuseram aos seus escravos uma carga inaudita de trabalho. (...) Diante do grande afastamento entre as linhas, o capataz ou feitor, postado na base do morro, conseguia visualizar facilmente o ritmo de andamento do trabalho e, portanto, impor sua aceleração quando julgasse necessário (MARQUESE, 2010, p. 97).
\end{abstract}

Como se verifica, trata-se de uma técnica de controle dos corpos pautada pela vigilância, com vista à máxima produtividade do trabalho escravos. Todavia, embora se trate de uma forma de controle visual, não se trata de uma reprodução do panóptico foucaultiano (paradigma da disposição arquitetônica do poder disciplinar). Em vez de uma vigilância impessoal e constante - a fomentar a introjeção do controle das condutas -, na plantation escravista ainda vige um modelo de vigilância pessoal, seja representada na figura do feitor, do administrador, ou do próprio senhor da propriedade. Essa forma de vigilância é cada vez mais pautada por diretrizes de produtividade dos corpos, mas não rompe de vez com a pessoalidade da vigilância. Mesmo nesses espaços marcados pela lógica da máxima produtividade, ainda vige uma forma de poder e dominação marcada pela pessoalidade.

Embora tendamos a concordar com as teses de Marquese e Koerner, nosso objetivo nessa pesquisa é comparar e analisar as diferentes práticas de controle e punição em diferentes espaços sociais. Partimos da premissa que as funções e papeis sociais cumpridos nas plantations escravistas diferentes daqueles dos espaços urbanos. A plantation fechava-se de tal forma que tendia a veicular uma forma própria de sociabilidade. Por sua vez, as cidades das regiões cafeicultoras não 


\section{ARTIGOS| Epigrafe \\ AS PRÁTICAS DE CONTROLE E PUNIÇÃO NA SOCIEDADE ESCRAVISTA CAFEICULTORA DO BRASIL OITOCENTISTA: UMA ANÁLISE À LUZ DO PENSAMENTO DE MICHEL FOUCAULT}

eram propriamente espaços de liberdade, mas detinham outras formas de articulação social, com escravos de ganho, libertos, homens livres e pobres, ou seja, relações sociais de outra natureza, não pautados pela rígida disciplina do trabalho nos cafezais.

Nesse sentido, nossa hipótese é a de que as formas de controle e das punições de escravos, segundo os termos dos manuais de agronomia analisados, consistiam em uma modalidade de expressão do poder mais próximo do poder disciplinar conforme descrito por Foucault. Embora concordemos que se trata de uma forma sui generis de expressão do poder, eis que mantém a pessoalidade e o paternalismo como características centrais da dominação - conforme constatado por Koerner -, nos parece que essa organização do trabalho contém algumas das principais característica do poder disciplinar.

É ainda mais interessante observar que os espaços onde essa forma de poder mais se concretizou são precisamente aqueles que melhor se articularam à economia mundial industrial do século XIX. Não se trata de expressar uma leitura economicista da tese de Foucault, mas de recordar sua afirmação de que, se não foi a burguesia que criou o poder disciplinar, certamente foi na consolidação da ordem burguesa e do sistema capitalista que essa forma de expressão do poder tornou-se hegemônica. Podemos pensar em uma espécie de 'afinidade eletiva' entre o poder disciplinar e o sistema econômico e de produção que se constituía no século XIX. Nesse sentido, os senhores que melhor se adaptaram ao novo contexto econômico foram aqueles que se destacaram na sociedade e na economia imperial precisamente aqueles que adotaram as técnicas de controle da escravaria e do trabalho produtivo mais eficientes.

Segundo a tese de Marquese, podemos pensar que se tratava de uma forma de expressão do poder que reafirmava a dominação pessoal dos senhores e extraía o máximo do trabalho escravo por meio de uma rígida disciplina dos corpos, e pela docilidade das mentes por meio do paternalismo, da conversão religiosa, e de benesses oferecidas pelo senhor (indo de mantimentos e roças à própria alforria). Uma combinação entre disciplina e paternalismo que permitiu ao Império brasileiro 


\section{ARTIGOS| Epigrafe}

MARCELO FERRARO

alcançar o monopólio virtual da oferta mundial de café no século XIX, sob o preço da consolidação de uma sociedade altamente hierarquizada e de uma exploração brutal dos trabalhadores escravizados.

\section{B) AS CASAS DE CÂMARA E CADEIA: UMA INTERPRETAÇÃO}

A formação dos espaços urbanos no Vale do Paraíba decorreria tanto de processos econômicos (produção e circulação de mercadorias), como de processos políticos - de consolidação de núcleos eleitorais e de instituições administrativas e representativas. Nesse quadro, o espaço urbano detinha amplo papel na produção, manutenção e expansão da riqueza e do poder dos senhores da região. Ao mesmo tempo, oferecia novas possibilidades econômicas e sociais a homens livres, libertos e escravos. Nesses novos ambientes, eram fomentadas novas formas de sociabilidade e novas relações políticas e sociais, que marcaram a sociedade imperial brasileira.

A Corte no Rio de Janeiro era a matriz cultural de todo o território nacional, de onde emanavam as ideias e princípios do projeto monárquico do Estado e da sociedade brasileira. Novos padrões de comportamento eram fomentados, a partir de matrizes culturais das nações civilizadas do noroeste europeu, e ressignificados na sociedade imperial (ALENCASTRO, 1997). As práticas sociais e culturas da Corte foram progressivamente adotadas pelos senhores do Vale, que se vinculavam aos símbolos e instituições de poder e status do Império.

Todavia, embora na Corte tenham surgido projetos como a CCC-RJ, e o policiamento fosse ostensivo - ante o elevado número de escravos de ganho e libertos nos espaços urbanos, as práticas punitivas e de controle nos espaços urbanos do Vale e de outras regiões interioranas não seguiram esse novo modelo institucional e arquitetônico de prisão. Embora transformadas, foram mantidas as Casas de Câmara e Cadeia como paradigma principal do edifício prisional.

As Casas de Câmara e Cadeia eram no período colonial a sede da administração e da justiça na esfera local. E tendo em vista a descentralização do poder, detinham relativa autonomia, ao menos até o surto minerador e as reformas 


\section{ARTIGOS| Epigrafe \\ AS PRÁTICAS DE CONTROLE E PUNIÇÃO NA SOCIEDADE ESCRAVISTA CAFEICULTORA DO BRASIL OITOCENTISTA: UMA ANÁLISE À LUZ DO PENSAMENTO DE MICHEL FOUCAULT}

pombalinas, que levaram a uma maior interferência da metrópole nas diretrizes locais. A condição de Vila ou cidade demandava a construção de uma igreja, de um pelourinho, e de um edifício destinado às funções de câmara (composta pelos 'homens bons' da localidade - proprietários de terras) e de prisão. Em alguns casos eram utilizados dois edifícios diferentes, um para cada função. Mas esse não era o padrão esperado de uma vila ou cidade de importância considerável, na qual a existência de uma Casa de Câmara e Cadeia era um elemento simbólico de poder e distinção (BARRETO, 1980, p. 110). Com a independência e a formação do Estado Imperial, os municípios mantiveram apenas parcialmente sua autonomia, perdendo poder ante os órgãos provinciais (após as reformas da década de 1830).

O programa arquitetônico das Casas de Câmara e Cadeia tinha por objetivo satisfazer necessidades de serviços administrativos e judiciários, penitenciários e religiosos. Os edifícios eram, em geral, compostos por dois pavimentos distintos. $\mathrm{O}$ pavimento superior era dividido em duas partes, uma destinada às atividades camarárias e outra para os serviços da judicatura. Já o pavimento térreo era destinado à cadeia. A segregação espacial desse pavimento obedecia apenas a critérios como sexo, raça e categoria social. Nesse sentido, não havia qualquer medida para segregar individualmente o preso (BARRETO, 1980, pp.147-150).

A localização do edifício era quase sempre na lateral do quadrilátero central da praça da Igreja Matriz. Tratava-se de um símbolo do poder e da riqueza da cidade e da região. Diversos ritos e festas públicas tinham início à frente desses edifícios, e com o avanço das tecnologias de iluminação, essas passavam a ser iluminadas à noite em períodos festivos. Como se observa, tratava-se de um monumento dotado de amplo caráter simbólico, com uma alusão tanto ao poder real como à autoridade municipal.

Após a independência, as Câmaras não eram mais apenas instituições administrativas da localidade de um Reino difuso cuja metrópole jazia distante, mas eram braços do Estado que se construía, adquirindo amplas funções. Embora perdessem parte de sua autonomia, detinham um poder de negociação e de articulação com as instituições provinciais e centrais do Império. Assim, embora 


\section{ARTIGOS| Epírafe \\ MARCELO FERRARO}

mantidas as Casas de Câmara e Cadeia, não se tratava da mesma instituição do período colonial, e tampouco o edifício reproduzia apenas as antigas funções. Ao mesmo tempo, uma constituição fora outorgada pelo imperador e um código de processo penal fora promulgado, organizando um novo sistema jurídico e administrativo, regulando tanto a esfera administrativa do Império como o sistema penal e prisional, segundo diretrizes do pensamento liberal da época.

As Casas de Câmara e Cadeia adquiriam progressivamente o papel de monumento simbólico do Estado em construção e da autonomia municipal, ao mesmo tempo em que abrigava as práticas administrativas e prisionais do novo Estado na esfera local.

\section{ANÁlise de CASO: A ARQUITETURA DA CASA DE CÂMARA E CADEIA DE VASSOURAS}

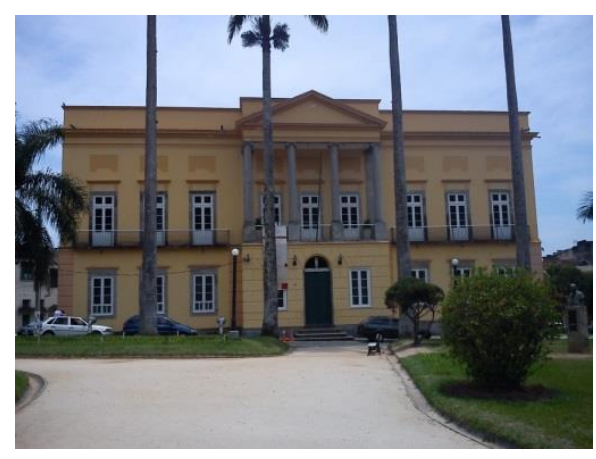

FIGURA $3^{6}$

A Casa de Câmara e Cadeia de Vassouras teve seu projeto idealizado e sua construção iniciada em 1849, ainda que a conclusão da obra somente tenha se dado em 1872 (BARRETO, 1980). Antes da conclusão da construção do edifício, as atividades camarárias e judiciárias se davam em espaços alugados. O mesmo ocorria com os presos, sendo guardados em uma casa alugada. Em 1840, o então presidente da Província do Rio de Janeiro, Paulino de Souza solicitava que Vassouras fosse a próxima cidade a ter financiada a construção de uma cadeia. Dois anos antes, Paulino de Souza visitara Vassouras dias antes da revolta dos escravos da Fazenda Maravilha, do capitão-mor Manuel Francisco Xavier (trata-se da fuga

\footnotetext{
${ }^{6}$ Câmara Municipal de Vassouras. Fotografia do Autor, 2011.
} 


\section{ARTIGOS| Epigrafe \\ AS PRÁTICAS DE CONTROLE E PUNIÇÃO NA SOCIEDADE ESCRAVISTA CAFEICULTORA DO BRASIL OITOCENTISTA: UMA ANÁLISE À LUZ DO PENSAMENTO DE MICHEL FOUCAULT}

liderada Manoel Congo, que trataremos mais adiante), e verificara por si próprio a insegurança da casa alugada para a guarda dos presos (SOUZA, 1971, pp. 48-49).

Embora José Antônio Soares de Souza (1971, pp. 19-51) afirme que a construção contou com verba provincial, outros estudos como o de Silva Telles alegam o financiamento por parte dos senhores de Vassouras. As quatro colunas monolíticas frontais do edifício aludiriam aos quatro principais financiadores da obra: O Barão de Vassouras, o Barão de Ribeirão, o Barão de Massambará e o Dr. Manuel Simões de Sousa Pinto (conceituado advogado de Vassouras, vinculado à família Leite Ribeiro). De toda forma, é interessante perceber as tênues fronteiras entre o financiamento público e privado das instituições. Cabe lembrar, ainda, que os cargos administrativos e judiciários eram preenchidos por membros das grandes famílias locais, eis que sua proeminência social e econômica os condicionava a pleitear cargos nas eleições, e a lograr os títulos acadêmicos (direito) que lhes permitiam o acesso aos cargos jurídicos.

A composição arquitetônica da Casa de Câmara e Cadeia obedecia aos critérios ideais dos edifícios dessas instituições. A existência de dois pavimentos permitia que o mesmo conjunto abrigasse as atividades camarárias, judiciárias e o espaço destinado aos presos. Enquanto o pavimento inferior destinava-se à cadeia, no superior se davam as atividades administrativas e judiciárias. É evidente a dimensão simbólica dessa solução arquitetônica, eis que a ordem institucional do Estado se reafirma em um status de superioridade (elemento espacial dotado de caráter simbólico qualitativo), sobrepondo-se àqueles que violam a legislação vigente. Para além de uma reafirmação do Estado, da ordem e da lei, há uma reprodução dos padrões de estratificação dessa sociedade. Em uma ordem constitucional que reafirmava categoricamente status diferenciados para os grupos sociais da população e defendia a ordem escravista, torna-se evidente que os dois pavimentos não eram destinados aos mesmos estratos sociais. Enquanto o espaço prisional era destinado basicamente a escravos e homens livres e pobres, o pavimento superior era acessível apenas aos 'homens bons' daquela sociedade (proprietários de terras e escravos, distintos socialmente por critérios legais e constitucionais). 


\section{ARTIGOS| Epigrafe \\ MARCELO FERRARO}

No que se refere ao papel prisional desse modelo arquitetônico, não nos encontramos sequer próximos do panóptico foucaultiano. Seus espaços internos são esquadrinhados, mas a segregação espacial do pavimento térreo obedecia apenas a critérios como sexo, raça e categoria social. Nesse sentido, não havia qualquer medida para segregar individualmente o preso (BARRETO, 1980, p. 150).Além disso, não havia um isolamento espacial da cadeia e do preso. Os presos das Casas de Câmara e Cadeia eram parte da paisagem urbana, e interagiam diretamente com o cotidiano urbano das vilas e cidades. Esse padrão pode ser observado na Casa de Câmara e Cadeia de Vassouras, a partir dessa fotografia de sua fachada lateral:

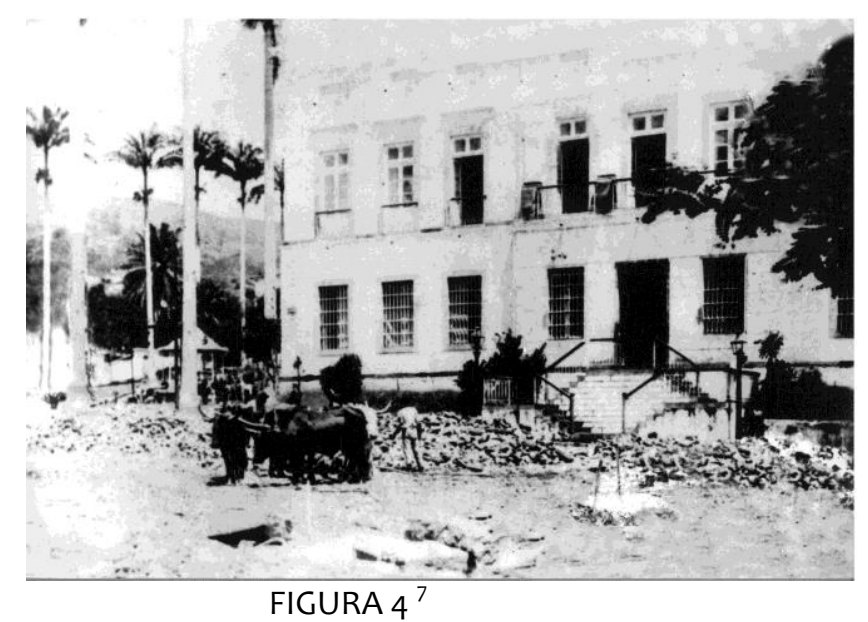

Nessa imagem ainda persistem as grades nas janelas do primeiro pavimento, onde eram abrigados os presos. Tendo em vista que se trata do núcleo urbano de Vassouras, os presos certamente tinham amplo contato com o cotidiano da população.

\footnotetext{
7 Fachada lateral da Casa de Câmara e Cadeia de Vassouras. Fotografia de autoria e data desconhecidas, descoberta pelo fotógrafo e pesquisador Othon de Almeida Filho.
} 


\title{
ARTIGOS| Epigrafe \\ AS PRÁTICAS DE CONTROLE E PUNIÇÃO NA SOCIEDADE ESCRAVISTA CAFEICULTORA DO BRASIL OITOCENTISTA: UMA ANÁLISE À LUZ DO PENSAMENTO DE MICHEL FOUCAULT
}

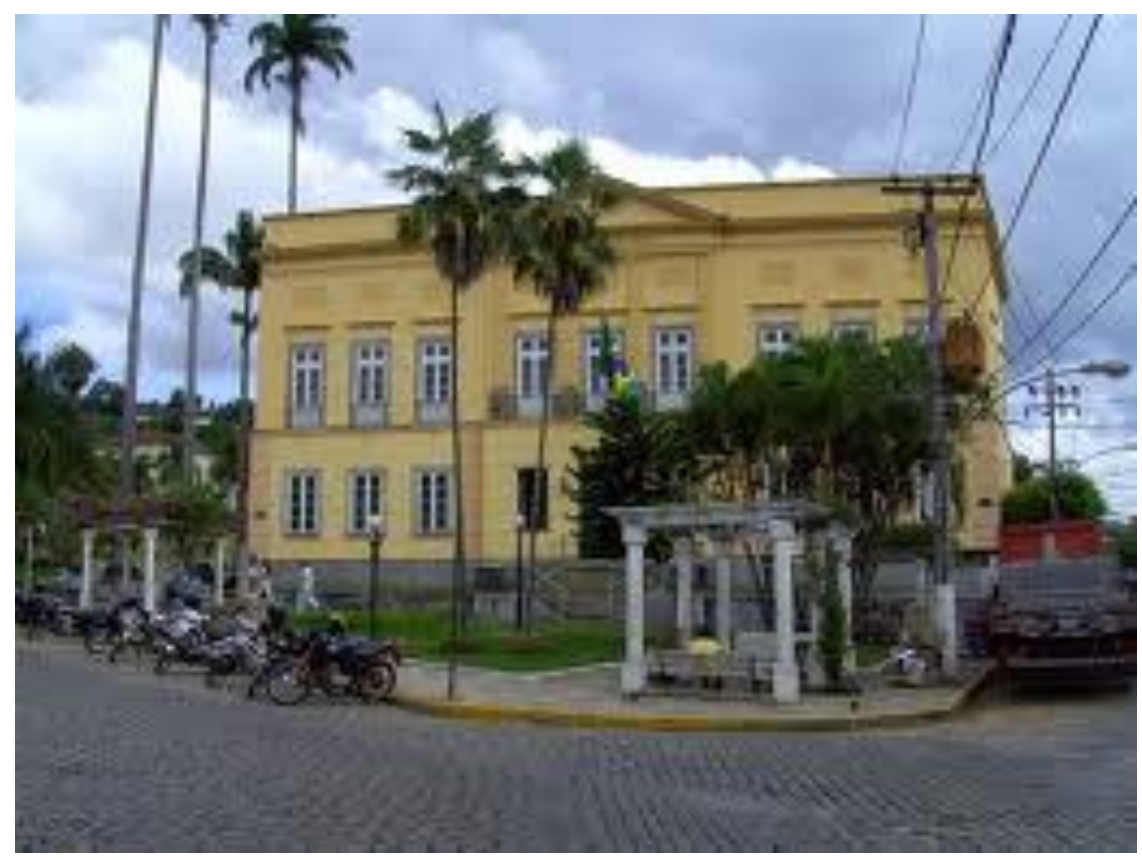

FIGURA $5^{8}$

Referindo-se ao padrão das cidades brasileiras, Barreto afirma:

\begin{abstract}
Os presos alimentavam-se da caridade pública ou de instituições pias e filantrópicas. Por vezes eram socorridos em alimento, remédio e roupa por beneméritas instituições que se chamam Casa de Misericórdia. Em datas festivas resolviam as Câmaras fornecer-Ihes alimento. Quando tal acontecia, enramalhetavam-se os carros precisos, carregados com mantimentos e carnes, desfilavam eles pelas ruas da cidade secundados por alguma música dos regimentos, com assistência e acompanhamento das altas autoridades e republicanos (BARRETO, 1980, p. 215).
\end{abstract}

Por sua vez, o viajante Auguste de Saint-Hilaire registrou que os presos eram vistos “às grades solicitando a piedade dos transeuntes ou conversando com eles. É necessário, aliás, que os encarcerados estejam, tanto quanto possível, em contato com os cidadãos, pois estes últimos é que os alimentam com suas esmolas" (SAINTHILAIRE apud BARRETO, 1980, p. 215).

Assim, não observamos qualquer medida no sentido de segregar espacialmente as cadeias nas regiões do Vale do Paraíba, assim como os próprios presos. Tampouco havia qualquer iniciativa no sentido de serem construídos nesses espaços edifícios prisionais segundo o modelo panóptico. Ao que tudo indica, a iniciativa relativamente frustrada da Casa de Correção da Corte não parece ter tido

\footnotetext{
${ }^{8}$ Mesma face do edifício atualmente (já sem as grades). Fotografia do Autor, 2011.
} 


\section{ARTIGOS| Epigrafe}

MARCELO FERRARO

qualquer medida correspondente no coração da cafeicultura e da escravidão oitocentista. Outras práticas punitivas, de controle social e outros modelos arquitetônicos foram adotados nesses espaços, tendo sido capazes de preservar a ordem escravista e hierárquica desses núcleos sociais por décadas.

Nessas sociedades, nem todos os crimes eram punidos com prisão, havendo outras penas para crimes brandos, e penas mais severas para insubordinações de escravos. A pena de prisão não se destinava a todos os estratos sociais da mesma forma, sendo geralmente destinadas a escravos e homens livres e pobres. Em geral essa pena remetia a crimes pecuniários e alguns envolvendo violência física.

Todavia, a condição de escravo e o tipo de crime cometido poderiam levar a penas bem mais severas. Analisemos três casos de penas para escravos na década de 1830 na região.

\footnotetext{
Na manhã do dia 16 de junho de 1836, Vassouras assistiu a um espetáculo macabro, a execução na forca de dois escravos africanos: João Preto de Nação Congo, que com uma faca matara sua mulher, Rosa, (...) e Matheus Rebolo, que atentara, sem sucesso, contra a vida de seu senhor, Joaquim de Bastos Valbão, (...). João Congo teria assassinado a esposa, acometido de 'ciúme cego' (...).

(...)Crimes passionais, sobretudo quando cometidos pelos maridos, não eram novidade na sociedade do Oitocentos e, quando punidos, não erma com pena capital. Mesmo quando praticados por escravos, outras soluções punitivas eram mais comuns. (...) As 'circunstâncias agravantíssimas' que me mereciam a exemplaridade da justiça eram outras. Deviam-se às origens de João Congo e ao perigo representado pelo que seu acusador considerava ser a sua cultura de origem nos quadros da sociedade escravista.

(...)A condenação de Matheus Rebolo por seu crime era mais rotineira na sociedade escravista imperial. Assassinatos ou tentativas de assassinato por parte de escravos contra seus senhores, e, às vezes, contra seus feitores, quase sempre, eram punidos com a morte.

(...) dois crimes cometidos em circunstâncias e datas diferentes, por escravos que não tinham relação entre si, eram punidos com o espetáculo de uma dupla execução pública, na mesma hora, no mesmo dia, no largo da Forca. Havia uma clara mensagem nesse espetáculo sinistro. Mensagem aos escravos: a lei dos senhores punia com rigor atos de rebeldia (...). Implicitamente, a mensagem deixava entrever o quanto os senhores se sentiam ameaçados pela presença africana (GRINBERG; BORGES; SALLES, 2009, pp. 242-243).
}

Por sua vez, Manoel Congo seria executado por um crime ainda mais grave. Em 1838 esse escravo liderou uma fuga em massa de uma plantation em Vassouras, 


\section{ARTIGOS| Epigrafe \\ AS PRÁTICAS DE CONTROLE E PUNIÇÃO NA SOCIEDADE ESCRAVISTA CAFEICULTORA DO BRASIL OITOCENTISTA: UMA ANÁLISE À LUZ DO PENSAMENTO DE MICHEL FOUCAULT}

libertando escravos das fazendas pelas quais passavam, somando cerca de 300 pessoas e rumando para as matas da região. Uma vez reprimidos, a maior parte dos escravos sofreu penas de açoite a alguns a galés. Todavia, no dia 06 de setembro de 1839, Manoel Congo, acusado e condenado pelos crimes de homicídio e insurreição, foi enforcado. Não bastasse, fora condenado à pena de morte 'para sempre', o que significava que seu cadáver ficaria à exposição até sua decomposição, sem receber sepultura religiosa. Embora não haja documentos que provem se tal tratamento foi dado a seu corpo, é certo que não recebeu os sacramentos fúnebres (GRINBERG;BORGES; SALLES, 2009, pp. 255-256).

Como se observa, no coração da escravidão oitocentista brasileira, mesmo nos espaços urbanos, havia práticas de suplício. Mas sua aplicação era basicamente restrita a escravos e a crimes nos quais haveria alguma forma de contestação ou ameaça ao poder soberano dos senhores. Nesse sentido, trata-se de uma lógica bastante próxima da tecnologia do suplício descrita por Foucault, pautada pelo caráter ostentatório do poder soberano, com a diferença que aqui se trata de uma soberania compartilhada entre o monarca e os senhores locais. Essas punições não tinham qualquer intuito de tornar os corpos de tais escravos mais úteis, mas destruílos como uma forma de expressar o poder soberano dos senhores sobre os escravos, deixando uma mensagem clara para o contingente de escravos da região.

Ao analisarmos as práticas punitivas nos espaços urbanos e a arquitetura prisional das Casas de Câmara e Cadeia, a quais conclusões chegamos? Tratar-se-ia de uma forma de expressão híbrida de poder, nos termos de Koerner? Seria uma tecnologia de poder mais ou menos próxima o poder disciplinar? Ou do poder soberano?

A partir do quadro analisado, podemos falar na coexistência de formas de tecnologias como o suplício e outras formas de punição e de expressão do poder. Nos espaços urbanos, especificamente, as formas de punição eram basicamente a prisão na Casa de Câmara e Cadeia, os açoitamentos no pelourinho e as execuções públicas na Forca. Se essas últimas consistem em práticas punitivas bastante próximas do suplício analisado por Foucault, a prisão na Casa de Câmara e Cadeia 


\section{ARTIGOS| Epigrafe}

MARCELO FERRARO

não se mostra uma forma de exercício do poder disciplinar. Sua manutenção na paisagem pública, a possibilidade de contato visual - pelas grades - com o restante da população, e a inexistência de uma rotina rígida pré-fixada, não permitem que nos refiramos a essa forma punitiva como uma tecnologia de poder assemelhada ao panóptico.

Sendo assim, cabe-nos interpretar o papel social cumprido pela arquitetura da Casa de Câmara e Cadeia na paisagem e no espaço urbano de Vassouras. Ao refletir sobre a arquitetura moderna da vigilância em Vigiar e Punir, Foucault faz a seguinte afirmação:

Toda uma problemática se desenvolve então: a de uma arquitetura que não é mais feita simplesmente para ser vista (fausto dos palácios), ou para vigiar o espaço exterior (geometria das fortalezas), mas para permitir um controle interior, articulado e detalhado - para tornar visíveis os que nela se encontram; mais geralmente, a de uma arquitetura que seria um operador para a transformação dos indivíduos: agir sobre aqueles que abriga, dar domínio sobre seu comportamento, reconduzir até eles os efeitos do poder, oferece-los a um conhecimento, modificá-los (...) (FOUCAULT, 1979, p. 166).

A partir do que observamos até aqui a arquitetura das Casas de Câmara e Cadeia, em especial a de Vassouras, parece reproduzir aquilo que Foucault apontou como uma arquitetura feita simplesmente para ser vista. Todavia, o regime visual contido nessa arquitetura possui muitas dimensões. Todo um campo semântico de discursos de poder é acionado a partir da inscrição da Casa de Câmara e Cadeia na paisagem. A localização das Casas de Câmara e Cadeia na lateral do quadrilátero central da praça da Igreja Matriz fazia dela um símbolo do poder e da riqueza da cidade e da região.

As Casas de Câmara e Cadeia eram ao mesmo tempo signos de vínculocom Estado imperial em construção e da autonomia municipal. E o edifício de Vassouras era motivo de orgulho para os habitantes da região, em especial os senhores locais. Sua presença na paisagem representava a inserção plena de Vassouras no quadro administrativo do Império, e consolidava o sucesso do projeto dos senhores locais em articularem de seus interesses com o plano político imperial. As palmeiras imperiais diante da face voltada à praça da Matriz são um elemento simbólico de 


\section{ARTIGOS| Epígrafe \\ AS PRÁTICAS DE CONTROLE E PUNIÇÃO NA SOCIEDADE ESCRAVISTA CAFEICULTORA DO BRASIL OITOCENTISTA: UMA ANÁLISE À LUZ DO PENSAMENTO DE MICHEL FOUCAULT}

alusão direta a essa relação entre poder local e a Corte (D‘ELBOUX, 2006).Seu caráter monumental e seu modelo arquitetônico (neoclássico) repetiam os padrões oriundos da Corte, remetendo a ideias de civilização e modernidade, ao mesmo tempo em que eram apropriados e reproduzidos os signos do poder imperial. Os senhores de Vassouras inscreviam na paisagem não apenas seu refinamento cultural e a pujança da cafeicultura da região, como seu poder político na ordem imperial.

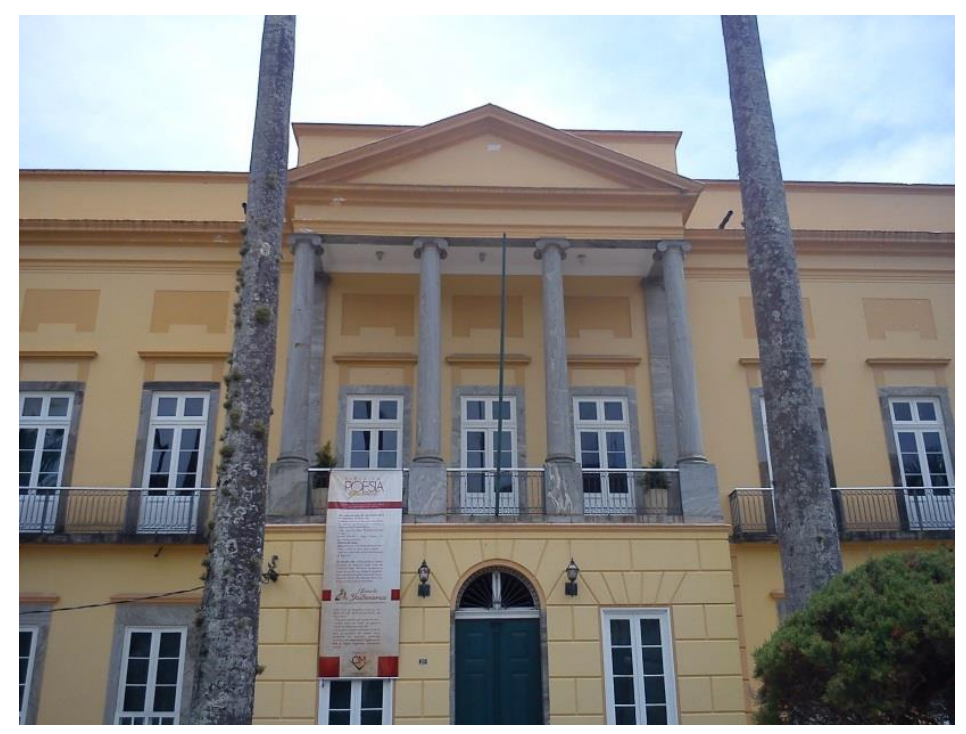

FIGURA $6^{9}$

No tocante a seu papel como instituição prática e simbólica da ordem social, rata-se de uma outra forma de expressão do poder, que tampouco se limita àquele observado nas plantations. Aqui o preso se mantém próximo à sociedade, mas segregado por grades. Ademais, o edifício em que se encontra contém toda uma disposição espacial que o coloca abaixo (pavimento inferior) - e subordinado - aos espaços destinados à administração e à justiça da sociedade imperial (pavimento superior). Há uma forma de controle e de expressão do poder que remete a uma dominação impessoal, como se a soberania em questão fosse institucional - das instâncias administrativas e jurídicas do Império. Todavia, essa impessoalidade sempre foi relativa na sociedade escravista brasileira, eis que os cargos administrativos e jurídicos eram sempre compostos pelos grandes senhores da

\footnotetext{
${ }^{9}$ Parte central da fachada voltada à praça, com as quatro colunas sob o frontão (traços da arquitetura neoclássica) e as palmeiras imperiais à frente. Fotografia de Marcelo Ferraro, 2011.
} 


\section{ARTIGOS| Epigrafe \\ MARCELO FERRARO}

região. A subordinação nunca se restringia ao caráter institucional de um cargo, remetendo à condição senhorial daquele que o ocupava.

Nesse sentido, a pena de prisão nas Casas de Câmaras e Cadeia reproduzia uma forma de controle social e de expressão do poder que associava instituições do Estado Imperial ao poder pessoal dos senhores, exercendo sobre os presos uma forma de expressão do poder supostamente impessoal, mas que reafirmava a ordem social hierárquica, o papel subordinado do presoe a posição dominante dos senhores. Sob uma pretensa legitimidade jurídico-formal, reproduziam-se as formas de dominação pessoal da sociedade escravista.

\section{IV) CONCLUSÃO}

Enquanto Koerner estuda a Casa de Correção da Corte, Marquese estuda a arquitetura das grandes plantations escravistas do Vale do Paraíba, ambos espaços do Império brasileiro. Ambas as formas de organização espacial reproduzem certas características: vigilância pessoal, espaços de invisibilidade, ostentação de instrumentos de violência. Diferentemente do panóptico, essas formas arquitetônicas reproduzem uma expressão pessoal de poder. Apesar de tais aproximações entre as teses de ambos, algumas diferenças devem ser pontuadas. A Casa de Correção da Corte de Koerner é uma instituição estatal voltada à manutenção da ordem urbana. Por sua vez, as grandes plantations escravistas do Vale do Paraíba são geridas por senhores e tem por objetivo o máximo de produtividade na cafeicultura.

Ao compararmos as práticas de controle e de punição nesses diferentes espaços, apresentamos uma primeira tese: ao que tudo indica, as plantations detinham uma forma de disciplina mais rigorosa e que visava ao constante aumento da produtividade dos trabalhadores. Precisamente por se tratar de uma unidade produtiva, e ser gerida por interesses econômicos dos senhores, nesses espaços foram gestadas formas cada vez mais elaboradas de gestão do trabalho dos escravos, com vista à docilidade de suas mentes e à máxima produtividade de seus corpos. Isso não significa que não houvesse práticas disciplinares visando à 


\section{ARTIGOS| Epigrafe \\ AS PRÁTICAS DE CONTROLE E PUNIÇÃO NA SOCIEDADE ESCRAVISTA CAFEICULTORA DO BRASIL OITOCENTISTA: UMA ANÁLISE À LUZ DO PENSAMENTO DE MICHEL FOUCAULT}

produtividade dos corpos na Casa de Correção da Corte. Mas aparentemente tais práticas não se deram com a mesma intensidade, e tampouco foram gestadas tantas teorias sobre a gestão dos presos.

De fato, concordamos com Koerner quando afirma que as formas de imposição de disciplina por meio da vigilância nunca se tornam impessoais como no panóptico. A disciplina tanto nas prisões como nas plantations é adquirida por meio de uma constante vigilância pessoal, concretizada na figura de carcereiros e funcionários das cadeias, feitores, administradores, senhores. No entanto, mesmo se tratando de uma forma de vigilância pessoal, as grandes plantations escravistas apresentaram novos saberes e novas práticas de controle e punição mais próximas daquilo que Foucault definiu como poder disciplinar.

É interessante observar que precisamente nos espaços articulados à ordem econômica pós-revolução industrial, tenham se tornado predominantes práticas disciplinares tão rigorosas. Embora as práticas disciplinares tenham surgido anteriormente em espaços específicos, é com a consolidação da ordem burguesa capitalistas que essas práticas disciplinares se tornam hegemônicas na sociedade, não apenas em instituições, mas se expressando por todas as redes de relações da sociedade. Aparentemente, foi nos espaços mais profundamente ligados à nova ordem econômica mundial que se desenvolveram mais firmemente as teorias e práticas disciplinares - e isso aproxima a realidade das indústrias europeias com a das plantations brasileiras.

Nesse sentido, as plantations escravistas do Vale do Paraíba reproduziriam teorias e práticas disciplinares mais intensas que aquelas observadas na Casa de Correção da Corte, essencialmente por sua função econômica imediata, com vista à produtividade máxima da cafeicultura, e à competição do produto no mercado mundial.

A essa tese acrescentamos uma segunda, que procura compreender as especificidades das instituições prisionais dos espaços urbanos do Vale do Paraíba, comparando-as tanto à Casa de Correção da Corte, como às plantations. Nas cidades e vilas do Vale não foram implementados projetos de instituições como a 


\section{ARTIGOS| Epigrafe \\ MARCELO FERRARO}

Casa de Correção da Corte, tampouco quaisquer outros programas arquitetônicos inspirados no panóptico de Bentham. Na maior parte do território brasileiro prevaleceu o modelo da Casa de Câmara e Cadeia, instituição que remonta ao período colonial. Ainda que tenha adquirido novas funções (administrativas e judiciárias) e uma nova importância na construção do Estado imperial, não houve profundas alterações em sua estrutura arquitetônica.

Foucault identificou uma profunda transformação na arquitetura de algumas instituições do século XIX. Como demonstrou Marquese, a arquitetura das plantations escravistas também se alterou profundamente na passagem para 0 século XIX, adquirindo inclusive algumas características panópticas. No entanto, as Casas de Câmara e Cadeia por todo o império mantiveram a estrutura arquitetônica do período colonial. As transformações se detiveram mais sobre o estilo das fachadas do que sobre o programa interno. Como explicar essas diferenças?

A Casa de Correção da Corte se encontrava no maior núcleo urbano do império, o Rio de Janeiro, onde uma grande população de escravos, libertos, homens livres e pobres circulavam diariamente. Esse quadro urbano demandava novas formas de controle social um novo sistema punitivo. Nesse sentido, ao recorrerem ao modelo arquitetônico do panóptico, as autoridades se mostravam atualizadas no debate acerca das formas modernas de controle social, observando realidades similares em países que se urbanizavam e industrializavam.

Por sua vez, as transformações da arquitetura das grandes plantations escravistas do Vale obedeciam a imperativos do mercado mundial do século XIX. As alterações arquitetônicas adotaram medidas voltadas à disciplina e à produtividade dos corpos dos escravos visavam interesses econômicos dos cafeicultores.

Diferentemente desses dos espaços da sociedade imperial, os núcleos urbanos interioranos do Vale do Paraíba não vivenciavam as mesmas realidades e não eram pautados pelos mesmos interesses. Embora houvesse uma população de escravos, libertos, e homens livres e pobres presente nesses espaços, não se tratava de uma realidade tensa como aquela observada na Corte. Desse modo as autoridades públicas de cidades como Vassouras não precisavam recorrer a 


\section{ARTIGOS| Epigrafe \\ AS PRÁTICAS DE CONTROLE E PUNIÇÃO NA SOCIEDADE ESCRAVISTA CAFEICULTORA DO BRASIL OITOCENTISTA: UMA ANÁLISE À LUZ DO PENSAMENTO DE MICHEL FOUCAULT}

tecnologias tão elaboradas e complexas como o panóptico. E tampouco as práticas de controle e punição nos espaços urbanos tinham por fim último a produtividade dos corpos, eis que era nas grandes plantations que esses imperativos se impunham.

Nossa segunda tese veicula a ideia de que nos espaços urbanos do Vale não eram dominantes os imperativos de mercado, e tampouco fazia-se necessária uma gestão meticulosa e disciplinar da população. Nos núcleos urbanos encontravam-se mercadores, tropeiros, pequenos comerciantes, religiosos, e residentes abastados. A ordem publica era mantida com relativo rigor, em especial com relação a escravos. Todavia, não se fazia necessária a gestação de novas tecnologias punitivas e teorias de gestão do controle social.

A arquitetura das Casas de Câmara e Cadeia se enquadravam no padrão que Foucault denominou como 'para ser vista'. As Casas de Câmara e Cadeia eram ao mesmo tempo signos de vínculo com Estado imperial em construção e da autonomia municipal.

Seu papel como instituição prisional não levava em conta os critérios do panóptico, uma vez que permanecia localizada no centro da vida social, e os presos faziam parte da paisagem urbana e da população das cidades. Por sua vez, os crimes considerados de maior potencial ofensivo eram aqueles perpetrados por escravos e que afrontavam a manutenção da ordem escravista e da hierarquia social. E esses casos eram punidos com grande rigor, fosse por meio de açoitamentos no pelourinho, fosse por meio do enforcamento público.

Ou seja, nos espaços urbanos do Vale vigia uma economia política das práticas de controle e punição pautadas pela visibilidade e publicidade. Toda forma de punição tendia a ocorrer ante os olhos da população, fosse no pelourinho, na Força, ou no pavimento térreo das Casas de Câmara e Cadeia. Nos espaços urbanos eram reproduzidas práticas punitivas mais próximas das formas de expressão poder soberano, primando pela ostentação e pela proximidade entre criminoso e sociedade. 


\section{ARTIGOS| Epírafe \\ MARCELO FERRARO}

E embora aqui nos refiramos a práticas punitivas estatais, e não privadas, não se trata de uma forma plenamente impessoal. Ainda que formalmente seja uma expressão do poder por meio de instituições e da lei, os cargos administrativos e jurídicos eram sempre compostos pelos grandes senhores da região. E a própria pena de prisão nas Casas de Câmaras e Cadeia reproduzia uma forma de controle social em que se confundiam instituições do Estado Imperial ao poder pessoal dos senhores. Basta lembrar a disposição arquitetônica do edifício, cujos pavimentos reproduziam uma gramática espacial e social rígida. Reproduzia-se no espaço e na paisagem a hierarquia social, naturalizada no cotidiano e legitimada constitucionalmente.

Eis, portanto, a segunda tese a que nos referimos. Nesses espaços predominavam relações de subordinação e deferência entre homens livres. Além disso, a construção do Império Constitucional Brasileiro alterou as regras do jogo pelo poder nessa sociedade. Não bastava a propriedade de terras e escravos para a imposição de sua vontade e de seus interesses. Os senhores tinham de sujeitar-se ao sistema eleitoral e à estrutura administrativa do Estado. Nesse sentido, eram necessárias articulações políticas, assim como um constante investimento em formas de clientelismo e paternalismo: com o fim de angariar um eleitorado constante.

A partir dessa constatação, adotamos a hipótese de que os espaços urbanos eram destinados a práticas sociais que fomentavam a reafirmação e legitimação do poder dos senhores nessa sociedade, tanto em relação aos escravos como em relação aos homens livres. A sociedade imperial que se formava levou à construção de um sistema político pautado por eleições e instituições representativas, mas cuja composição serviu à manutenção de uma ordem social hierárquica. Os cargos eletivos foram apropriados por senhores locais e utilizados como instrumentos de manutenção e aumento de seu prestígio, poder e fortuna. A manutenção dessa ordem social demandava a veiculação de um discurso de deferência social ante tais senhores. 


\section{ARTIGOS| Epigrafe \\ AS PRÁTICAS DE CONTROLE E PUNIÇÃO NA SOCIEDADE ESCRAVISTA CAFEICULTORA DO BRASIL OITOCENTISTA: UMA ANÁLISE À LUZ DO PENSAMENTO DE MICHEL FOUCAULT}

Por essa razão, as práticas punitivas aproximavam-se das formas de expressão do poder soberano, pautadas pela ostentação do poder das instituições e dos senhores que as compunham. Assim, os espaços urbanos seriam um dos palcos privilegiados das disputas e articulações políticas dos senhores, onde se davam as eleições, e se encontravam as instituições administrativas e judiciárias da municipalidade. Era a manutenção da hierarquia social e a disputa pela deferência de toda a sociedade que pautavam as práticas sociais nesses espaços urbanos ${ }^{10}$.

Dessa forma, a Casa de Câmara e Cadeia detinha objetivos que em muito superavam as demandas por controle social e punição de criminosos. A disciplina e produtividade dos seus corpos não eram as diretrizes que orientavam o modelo arquitetônico vigente. A Câmara era mais importante que a Cadeia, e a disposição espacial de ambas reafirmava a hierarquia e a ordem.

Portanto, a comparação entre as disposições arquitetônicas da Casa de Correção da Corte, as Casa de Câmara e Cadeia dos espaços urbanos e das grandes plantations cafeeiras do Vale do Paraíba do Vale, nos permite extrair conclusões acerca das diversas realidades sociais encontradas na sociedade imperial, assim com as formas de expressão de poder nela presentes.

$\mathrm{Na}$ Corte prevaleceram as tentativas de controle da massa populacional, com adoção de tecnologias disciplinares como o panóptico. No entanto, a realização apenas parcial dessa estratégia denota a dificuldade de se instituir uma ordem impessoal da lei, sendo mantida a dominação pessoal. Por sua vez, as grandes plantations constituíram-se como espaços disciplinares rigorosos, nos quais foram produzidas as principais teorias de gestão do trabalho, sempre com vista à máxima produtividade. Por fim, as Casas de Câmara e Cadeia se inseriam em contextos sociais nos quais a imposição da ordem hierárquica e do poder dos senhores se

\footnotetext{
${ }^{10} \mathrm{O}$ escravo liberto, desde que nascido no Brasil, adquiria cidadania e direitos constitucionais. Nesse sentido, sua alforria poderia ser instrumentalizada pelos senhores com vista à manutenção de uma clientela fica. Ver a ideia de paternalismo liberal em PARRON, 2011. Ver ainda BERBEL; MARQUESE; PARRON, 2010.
} 


\section{ARTIGOS| Epírafe \\ MARCELO FERRARO}

sobrepunha às medidas de controle da população escrava e livre. Por meio da articulação política entre si, e com os demais grupos políticos e instituições do império, os senhores do Vale implementavam um projeto de manutenção de seu poder e de seu status privilegiado na ordem vigente, sendo os espaços urbanos o lócus privilegiado de sua atuação.

\section{IMAGENS}

FIGURA 1: Georg Grimm [atribuição], Fazenda Boa Vista (detalhe), Bananal, SP, óleo sobre tela,ca. 1880, 74cm x 144cm (SETUBAL, 2004, p.160; MARQUESE, , 2006, p. 26).

FIGURA 2: Osmar Cassiano Gomes Jr., Fazenda Boa Vista, 2005, planta baixa (MARQUESE, 2006, p.26).

FIGURA 3: Fotografia de Marcelo Ferraro (autor). Ano de 2011.

FIGURA 4: Fotografia de autoria e data desconhecidas, descoberta pelo fotógrafo e pesquisador Othon de Almeida Filho, e disponibilizada ao autor.

FIGURA 5: Fotografia de Marcelo Ferraro (autor). Ano de 2011.

FIGURA 6: Fotografia de Marcelo Ferraro (autor). Ano de 2011.

\section{FONTES IMPRESSAS}

FONSECA, Padre Antonio Caetano da.Manual do Agricultor dos gêneros alimentícios. ( $2^{\mathrm{a}}$ ed.). Rio de Janeiro: Laemmert, 1864.

Instruções para a comissão permanente nomeada pelos fazendeiros do município de Vassouras. Rio de Janeiro, 1984, apud GOMES, Flávio dos Santos. Histórias de Quilombolas - mocambos e comunidades escravas no Rio de Janeiro - Século XIX. Rio de Janeiro, Arquivo Nacional, 1995, p. 282.

TAUNAY, Carlos Augusto. Manual do Agricultor Brasileiro (1 ${ }^{a}$ ed., 1839). Organização de Rafael de Bivar Marquese. São Paulo: Companhia das Letras, 2001.

WERNECK, Francisco Peixoto de Lacerda. Memórias sobre a Fundação de uma Fazenda na Província do Rio de Janeiro. Organização de Eduardo Silva. Rio de Janeiro: Fundação Casa de Rui Barbosa - Brasília: Senado Federal, 1985.

WERNECK, Luís Peixoto de Lacerda. Ideas sobre colonisação, precedidas de uma succinta exposição dos princípios geraes que regem a população. Rio de Janeiro: Laemmert, 1855. 


\section{ARTIGOS| Epigrafe \\ AS PRÁTICAS DE CONTROLE E PUNIÇÃO NA SOCIEDADE ESCRAVISTA CAFEICULTORA DO BRASIL OITOCENTISTA: UMA ANÁLISE À LUZ DO PENSAMENTO DE MICHEL FOUCAULT}

\section{REFERÊNCIAS BIBLIOGRÁFICAS}

ADORNO, Sérgio. Foucault, a Lei e o Direito. In: SCAVONE, Lucila; ALVAREZ, Marcos César; MISKOLCl, Richard. (Orgs.). O Legado de Foucault. São Paulo: Ed. UNESP, 2006.

ALENCASTRO, Luiz Felipe de. Vida Privada e Ordem Privada no Império. In: (org.); NOVAIS, Fernando (coord.). História da Vida Privada no Brasil. vol II. Império: A Corte e a Modernidade Nacional. São Paulo: Companhia das Letras, 1997.

BARRETO, Paulo Thedin. Casas de Câmara e Cadeia. In: Arquitetura Oficial I. Textos escolhidos da Revista do Instituto do Patrimônio Histórico e Artístico Nacional. São Paulo: FAU/USP, 1980.

BERBEL, Márcia; MARQUESE, Rafael, PARRON, Tamis. Escravidão e Política. Brasil e Cuba, 1790-1850. São Paulo: Hucitec/FAPESP, 2010.

D’ELBOUX, Roseli Maria Martins. Manifestações Neoclássicas no Vale do Paraíba: Lorena $e$ as Palmeiras Imperiais. Dissertação de Mestrado. São Paulo: Faculdade de Arquitetura e Urbanismo, 2004.

. Uma promenade nos trópicos: os barões do café sob as palmeirasimperiais, entre o Rio de Janeiro e São Paulo. Anais do Museu Paulista, São Paulo. v.14. n.2, pp. 193-250, jul-dez, 2006.

FOUCAULT, Michel. Vigiar E Punir: O Nascimento Da Prisão. Tradução de Raquel Ramalhete. 29 a Edição. Petrópolis: Ed. Vozes, 2004.

- Microfísica do Poder. Organização e tradução de Roberto Machado. Rio de Janeiro: Graal, 1979.

FRANCO, Maria Sylvia de Carvalho. Homens Livres na Ordem Escravocrata. São Paulo: Fundação Editora UNESP, 1997.

GRINBERG, Keila; BORGES, Magno Fonseca; SALLES, Ricardo. Rebeliões Escravas antes da extinção do Tráfico. In: GRINBERG, Keila; SALLES, Ricardo (orgs.). $O$ Brasil Imperial. Volume II - 1831-1870. Rio de Janeiro: Civilização Brasileira, 2009.

KOERnER, Andrei. Punição, Disciplina e Pensamento Penal no Brasil do Século XIX. Lua Nova, São Paulo, 68: 205-542, 2006.

- O Impossível 'Panóptico Tropical-Escravista': Práticas Prisionais, Política e Sociedade no Brasil do Século XIX. Revista Brasileira de Ciências criminais, 35, Ano 9, Julho-Setembro, 2001, pp. 211-224. 


\section{ARTIGOS| Epírafe \\ MARCELO FERRARO}

MARQUESE, Rafael de Bivar. Feitores do Corpo, Missionários da Mente.Senhores, Letrados e o controle dos escravos na América, 1660-1860. São Paulo: Companhia das Letras, 2004.

- Revisitando casas-grandes e senzalas: a arquitetura das plantations escravistas americanas no século XIX. Anais do Museu Paulista (Impresso), v. 14, p. 11-57, 2006.

- O Vale do Paraíba cafeeiro e o regime visual da segunda escravidão: o caso da fazenda Resgate. Anais do Museu Paulista (Impresso), v. 18, pp. 83-128, 2010.

PARRON, Tamis. A Política da Escravidão no Império do Brasil, 1826-1865. Rio de Janeiro: Civilização Brasileira, 2011.

SALLA, Fernando; GAUTO, Maitê; ALVAREZ, Marcos Cesar. A Contribuição de David Garland: a Sociologia da Punição. Tempo Social, São Paulo: FFLCH/USP, vol. 18, $\mathrm{n}^{\circ}$ 1, pp. 329-350, 2006.

SOUSA, José Antônio Soares de. Vassouras e suas Residências Urbanas. Revista do IHGB, n² 290, jan-mar.,1971.

TELLES, Augusto Carlos da Silva. Vassouras, Estudo da Construção Residencial Urbana. In: Revista do Patrimônio Históricoe Artístico Nacional,Rio de Janeiro, v.16, pp. 9-135, 1968.

TOMICH, Dale. Pelo Prisma da Escravidão. São Paulo: Edusp, 2011. 